\title{
Mechanism of TGF- $\beta 1$ inhibiting Kupffer cell immune responses in cholestatic cirrhosis
}

\author{
JUN QIAN*, YUWEN JIAO*, GUANGYAO WANG, HANYANG LIU, XIANG CAO and HAOJUN YANG \\ Department of General Surgery, The Affiliated Changzhou No. 2 People's Hospital of \\ Nanjing Medical University, Changzhou, Jiangsu 213000, P.R. China
}

Received August 19, 2019; Accepted January 15, 2020

DOI: $10.3892 /$ etm.2020.8826

\begin{abstract}
Effect of exogenous transforming growth factor- $\beta 1$ (TGF- $\beta 1$ ) on cholestatic mice by inhibiting Kupffer cell immune responses in liver was investigated. To induce cholestasis, BALB/c mice received a sham operation (Mock group), or underwent a bile duct ligation (BDL group) and then were subcutaneously injected with TGF- $\beta 1$ at multiple sites (TGF group). Liver functions were evaluated according to the levels of alanine aminotransferase (ALT), aspartate aminotransferase AST and $\gamma$-glutamyltranspeptidase $(\gamma$-GT) in serum samples. Expression of nuclear factor- $\kappa \mathrm{B}(\mathrm{NF}-\kappa \mathrm{B})$, interleukin-6 (IL-6), IL-1 $\beta$ and tumor necrosis factor- $\alpha$ (TNF- $\alpha)$ was detected. Expression of inducible nitric oxide synthase (iNOS) and arginase-1 (Arg-1) in Kupffer cells (KCs) of the liver was detected. The isolated KCs were divided into control group, LPS group, TGF group and Galunisertib group and western blot analysis was used to detect the expression of NF- $\kappa \mathrm{B}$, IL- 6 , IL-1 $\beta$, TNF- $\alpha$, iNOS and Arg-1. The percentage of CD40, CD86, CD204 and CD206 as macrophage cell surface antigens were measured by flow cytometry. The indexes of liver function and liver fibrosis of the mice in the TGF group were significantly lower than those in the BDL group $(\mathrm{P}<0.05)$. The levels of IL-1 $\beta$, IL- 6 and TNF- $\alpha$ in the liver were lower than those in the BDL group, while the level of IL-10 was significantly increased $(\mathrm{P}<0.05)$. M2-type transformation occurred in liver Kupffer cells of mice in the TGF group. In cell experiments, TGF treatment downregulated the expression of IL-1 $\beta$, IL-6, TNF- $\alpha$ and NF- $\kappa$ B, increased the expression of IL-10, and induced M2-type transformation in macrophages $(\mathrm{P}<0.05)$. In conclusion, TGF- $\beta 1$ diminished the progression of cholestasis
\end{abstract}

Correspondence to: Dr Haojun Yang, Department of General Surgery, The Affiliated Changzhou No. 2 People's Hospital of Nanjing Medical University, 68 Gehu Zhong Road, Changzhou, Jiangsu 213000, P.R. China

E-mail: rrvver@163.com; yhjmr@163.com

\section{*Contributed equally}

Key words: TGF, Kupffer cells, inflammatory response, cholestatic cirrhosis in mice by inhibiting the inflammatory response of $\mathrm{KCs}$ and regulating $\mathrm{KC}$ polarization.

\section{Introduction}

A cholestatic liver disease (CLD) arises during bile formation and/or flow dysfunction due to genetic, immune, environmental or other factors, developing into severe hepatobiliary diseases and systemic sequelae (1). When cholestasis occurs, the level of bile acids in liver and serum rises sharply and ends up with acute hepatotoxicity, bile duct proliferation and even hepatic fibrosis $(2,3)$. Therefore, it is urgent to explore the mechanism by which cholestatic hepatitis develops, and find new targets $(4,5)$.

Inflammatory responses are often found in the process of fibrosis (6) as an increase in the levels of inflammatory cytokines and a decrease in anti-inflammatory cytokines $(7,8)$. Macrophages are multifunctional immune cells in the innate immune system, which remove apoptotic cells by phagocytose, present antigens, and produce pro-inflammatory cytokines and chemokines, such as interleukin-1 $\beta$ (IL-1 $\beta$ ), IL-6, and tumor necrosis factor- $\alpha$ (TNF- $\alpha)(9,10)$. When an organ is infected or overwhelmed with inflammation, macrophages first differentiate into M1 to release pro-inflammatory cytokines against the stimulus, including TNF- $\alpha$, interleukin-1 $\beta$ (IL-1 $\beta$ ), IL-12 and IL-23 (11). In order to offset this, M2 macrophages secrete a large number of such anti-inflammatory cytokines as IL-10 and transforming growth factor- $\beta 1$ (TGF- $\beta 1$ ), while contributing to angiogenesis, tissue repair and remodeling $(12,13)$. It means that M2 macrophages suppress inflammation, promote tissue remodeling, and bring a return to tissue homeostasis, following the initial M1-macrophage-induced response $(14,15)$. M1/M2 macrophages are in dynamic equilibrium under normal circumstances, but when macrophage polarization is biased towards M1, the homeostasis evolves to an inflammatory response to damage peripheral tissue and activate immune system, which may be one of the major factors behind autoimmune liver diseases.

TGF- $\beta 1$ is the most involved molecule (16) and may be produced by multiple cell types. Focus has been mainly on its biological functions in embryonic development and tissue repair and recently on its key regulation of the immune cell functions $(17,18)$. TGF- $\beta 1$ has $99 \%$ (19) homology between human and mice, and was given the only priority in the study 
to explore its effect on macrophage immune responses. By regulating the chemotaxis, activation and transformation of immune cell varieties, TGF- $\beta 1$ controls the process of inflammatory response in the body (20). TGF- $\beta 1$ is associated with polydysplasia and various human diseases, including cancer, fibrosis and autoimmune diseases $(21,22)$. The severity of PBC may be indicated by TGF- $\beta 1$, a marker of fibrosis $(23,24)$. Tang et al (25) found that TGF- $\beta 1$ played a dual role in PBC progression, inhibitiing inflammatory response while enhancing fibrogenesis.

By animal trial and cell trial, this study explored whether TGF- $\beta 1$ can affect the progression of cholestatic cirrhosis in mice by suppressing the immune response of Kupffer cells (KCs). It might bring clinical treatment of cholestatic cirrhosis into a new direction.

\section{Materials and methods}

Laboratory animals and main reagents. Six-week-old male BALB/c mice were purchased from Changzhou Cavens Lab Animal Co., Ltd. with an animal license number of SCXK (Su) 2016-0010. TGF- $\beta 1$ (ab50036), NF-кB (ab131546; 1:1,000 dilution), IL-6 (ab7737; 1:20 dilution), IL-1 $\beta$ (ab9722; $0.2 \mu \mathrm{g} / \mathrm{ml}), \mathrm{TNF}-\alpha$ (ab6671; 1:1,000 dilution), inducible nitric oxide synthase (iNOS) (ab15323; 1:200 dilution), Arg-1 antibody (ab91279; $1 \mu \mathrm{g} / \mathrm{ml})$, goat anti-rabbit IgG secondary antibody (ab6721; 1:10,000 dilution), glyceraldehyde 3-phosphate dehydrogenase (GAPDH) antibody (ab181602; 1:300 dilution), CD40 antibody (ab22469; $10 \mu \mathrm{l} / 10^{6}$ cells), CD80 antibody (ab106162; $10 \mu 1 / 10^{6}$ cells) and CD206 antibody (ab64693; $10 \mu 1 / 10^{6}$ cells) were supplied by Abcam; CD204 antibody (50129-R004-F; $10 \mu 1 / 10^{6}$ cells) by Sino Biological Inc. Fetal bovine serum, DMEM and ECL were supplied by Gibco; Thermo Fisher Scientific, Inc. RIPA lysis buffer and BCA protein assay kit were supplied by Yubo Biology Co., Ltd. RNA extraction kit, reverse transcription kit and polymerase chain reaction (PCR) reagent were supplied by Baiaolaibo. Synthesized PCR primer was supplied by BGI. Galunisertib and LPS were supplied by Selleck. IV collagenase (17104019) was from Gibco; Thermo Fisher Scientific, Inc. Type III procollagen N-terminal peptide (PIIINP) (SXM074), type IV collagen (IVC) (SXM075), laminin (LN) (SXM077), hyaluronidase (HA) (SXM078) kits were from Shanghai Runwell technology Co., Ltd.

The study was approved by the Ethics Committee of The Affiliated Changzhou No. 2 People's Hospital of Nanjing Medical University (Changzhou, China).

Establishment and grouping of animal models. As previously described (2), 40, 6-week-old BALB/c mice were included in the trial to randomly receive a sham operation (Mock group, $n=10$ ), bile duct ligation (BDL group, $n=15$ ) or BDL and TGF treatment (TGF group, $n=15$ ). Mice were raised in SPF laboratory animal room and given the same animal feed and drinking water. The animal room was provided with natural light and was well ventilated, with the temperature of $20-25^{\circ} \mathrm{C}$. The experiment began after adaptive feeding for one week. After fasting for $8 \mathrm{~h}$, mice were anesthetized via intraperitoneal injection of $0.3 \%$ pentobarbital sodium at the dose of $45 \mathrm{mg} / \mathrm{kg}$ and then dissected to separate the common bile duct. The common bile duct was ligated in the BDL group and TGF group, whereas, it was isolated rather than ligated before the closure of the abdominal cavity in the Mock group. The entire trial was carried out under aseptic conditions. TGF group was injected subcutaneously with $1 \mu \mathrm{g}$ TGF- $\beta 1$ at multiple sites on days $0,2,4,6$ and 8, respectively. They were maintained in the specific-pathogen-free (SPF) laboratory for 11 days and sacrificed by breaking the neck to draw blood samples through portal veins. Liver tissue obtained was stored in liquid nitrogen. During the experiment, no mice died due to adverse events or poor postoperative recovery.

Total protein extraction. To extract total protein from liver tissue: $100 \mathrm{mg}$ of liver tissue was separated from mice, sliced as much as possible with sterilized scissors and put into $1.5-\mathrm{ml}$ EP tube. The tube was added with $0.5 \mathrm{ml}$ RIPA lysis buffer on ice to homogenize with an ultrasonic homogenizer and placed on ice again for $30 \mathrm{~min}$. Subsequently, the liver tissue was centrifuged at $4^{\circ} \mathrm{C}$ and $13,780 \mathrm{x}$ g for $5 \mathrm{~min}$ to extract the supernatant, then the supernatant was separated in $0.2 \mathrm{ml}$ centrifuge tubes and stored at $-20^{\circ} \mathrm{C}$.

To extract total protein from KCs: KCs were isolated from mouse livers according to previous research (26) and collected in a dish which was then added with lysis buffer at the bottom. Left standing for $5 \mathrm{~min}$, cell lysate was scraped into $1.5 \mathrm{ml} \mathrm{EP}$ tubes, and centrifuged at $4^{\circ} \mathrm{C}$ and $13,780 \mathrm{x} \mathrm{g}$ for $20 \mathrm{~min}$ after being placed on ice for $30 \mathrm{~min}$, to extract the supernatant as the total protein. Then the extract was subpackaged in $0.2 \mathrm{ml}$ centrifuge tubes and stored at $-20^{\circ} \mathrm{C}$ for subsequent steps.

KCs isolation and culture. With the reported method (27), $\mathrm{KCs}$ in the liver of mice in Mock group, BDL group and TGF group were isolated. In addition, 20 6-week-old BALB/c mice without any experiment were raised in SPF laboratory animal room and given the same animal feed and drinking water. The animal room was provided with natural light and was well ventilated, with the temperature of $20-25^{\circ} \mathrm{C}$. Subsequently, the mice were sacrificed by neck-breaking to isolate $\mathrm{KCs}$. The specific method was: the blood in the liver was removed by portal vein perfusion with $10 \mathrm{ml}$ of calcium-free Hank balanced salt solution. The liver tissue was minced and incubated in a container containing 50 units of type IV collagenase for $30 \mathrm{~min}$ at $37^{\circ} \mathrm{C}$. The liver homogenate filtrate was then subjected to discrete gradient centrifugation to isolate non-parenchymal cells. The obtained cells were further incubated at $37^{\circ} \mathrm{C}$ with $5 \% \mathrm{CO}_{2}$ for $2 \mathrm{~h}$ to obtain $\mathrm{KCs}$ after removing non-adherent cells. $\mathrm{KCs}$ were collected from mice in the two experiments for later use. The final density of the collected KCs was $1 \times 10^{6} /$ well. Cells isolated from the liver of 6-week-old BALB/c mice without any experiments were divided into control group, LPS group, TGF group and Galunisertib group. LPS group was treated with $100 \mathrm{ng} / \mathrm{ml}$ LPS for $12 \mathrm{~h}$; TGF group was pretreated with $10 \mathrm{ng} / \mathrm{ml} \mathrm{TGF}$ for $3 \mathrm{~h}$, then stimulated with $100 \mathrm{ng} / \mathrm{ml} \mathrm{LPS}$, and cultured for $12 \mathrm{~h}$; Galunisertib group was pretreated with $10 \mu \mathrm{M}$ Galunisertib and $10 \mathrm{ng} / \mathrm{ml}$ TGF for $3 \mathrm{~h}$, and then cultured with $100 \mathrm{ng} / \mathrm{ml}$ LPS for $12 \mathrm{~h}$.

RNA extraction. The cells were washed twice with phosphatebuffered saline (PBS). After the addition of $1 \mathrm{ml}$ of TRIzol, the cells were put an ice until there was no significant precipitation 
Table I. The sequences of the primers.

\begin{tabular}{lll}
\hline Genes & \multicolumn{1}{c}{ Forward primers } & \multicolumn{1}{c}{ Reverse primers } \\
\hline TNF- $\alpha$ & 5'-CATACCAGGAGAAAGTCAGC-3 & 5'-CTAAGTACTTGGGCAGGTTG-3' \\
IL-6 & 5'-GTTCTCTGGGAAATCGTGGA-3' & 5'-TGTACTCCAGGTAGCTA-3' \\
IL-1 $\beta$ & 5'-CCAGGATGAGGACATGAGCA-3' & 5'-CGGAGCCTGTAGTGCAGTTG-3' \\
GAPDH & 5'-TCAACGGGGGACATAAAAGT-3' & 5'-TGCATTGTTTTACCAGTGTCAA-3'
\end{tabular}

TNF- $\alpha$, tumor necrosis factor- $\alpha$; IL, interleukin; GAPDH, glyceraldehyde 3-phosphate dehydrogenase.

in the lysate; then transfer to a clean $1.5 \mathrm{ml}$ EP tube and left to stand at room temperature for $5 \mathrm{~min}$.

Chloroform $(200 \mu \mathrm{l})$ was added, the centrifuge tube was covered, shaken at room temperature for $15 \mathrm{sec}$, and then the solution was fully emulsified. After standing at room temperature for $5 \mathrm{~min}$, centrifugation at $13,780 \mathrm{x} \mathrm{g}$ for $15 \mathrm{~min}$ at $4^{\circ} \mathrm{C}$, and the supernatant was transferred to a new EP tube.

Isopropanol $(0.5 \mathrm{ml})$ was added and allowed to stand at $4{ }^{\circ} \mathrm{C}$ for $20 \mathrm{~min}$ to precipitate RNA, followed by centrifugation at $13,780 \mathrm{x} \mathrm{g}$ for $15 \mathrm{~min}$ at $4^{\circ} \mathrm{C}$. The supernatant was removed and transferred to a new EP tube, washed with $1 \mathrm{ml}$ of $75 \%$ ethanol. After the mixing, the mixture was centrifuged at $13,780 \mathrm{x} g$ at $4^{\circ} \mathrm{C}$ for $20 \mathrm{~min}$, and the supernatant was discarded.

The precipitate was dried at room temperature for 2-5 $\mathrm{min}$, and an appropriate amount of DEPC water was added to dissolve the RNA precipitate.

The nucleic acid quantifier NanoDrop2000 was used to test the ratio of A260/A230 and A260/A280 to detect the extraction effect of fecal DNA.

Real-time PCR detection. Real-time PCR is a technique to detect the mRNA level of inflammatory cytokines. The sequences of the primers are shown in Table I.

PCR reaction system is shown in Table II. The detailed reaction steps are as follows: Predenaturation at $98^{\circ} \mathrm{C}$ for $30 \mathrm{sec}$. After predenaturation, 35 cycles of routine PCR amplification were performed, including denaturation at $98^{\circ} \mathrm{C}$ for $10 \mathrm{sec}$, annealing at $54^{\circ} \mathrm{C}$ for $30 \mathrm{sec}$, extension at $72^{\circ} \mathrm{C}$ for $45 \mathrm{sec}$ and finally extended at $72^{\circ} \mathrm{C}$ for $10 \mathrm{~min}$.

In the experiment, three multiple wells were made for each sample, and the starting copy number of the target gene in the sample was calculated by comparing the measured $\mathrm{Ct}$ value with the standard curve.

Western blot analysis. The protein concentration of liver extract and KCs extract was quantified by BCA Protein Assay. Then transfered onto PVDF membrane at $100 \mathrm{~V}$ after SDS-PAGE, and blocked with 5\% skim milk at room temperature for $1 \mathrm{~h}$. The liver extract was incubated overnight at $4^{\circ} \mathrm{C}$ with $\mathrm{NF}-\kappa \mathrm{B}$ (diluted at 1:1,000), IL-6 (diluted at 1:20), IL-1 $\beta(0.2 \mu \mathrm{g} / \mathrm{ml})$ and TNF- $\alpha$ (diluted at 1:1,000) primary antibodies, which was roughly the same procedure as that for the $\mathrm{KC}$ extract with the exception that the additives were iNOS (diluted at 1:200) and Arg-1 $(1 \mu \mathrm{g} / \mathrm{ml})$ primary antibodies. In addition, the $\mathrm{KC}$ extract was subsequently incubated overnight with GAPDH (diluted at $1: 300$ ) primary antibody at $4^{\circ} \mathrm{C}$, and with secondary
Table II. PCR reaction system.

\begin{tabular}{lc}
\hline PCR reaction element & PCR reaction volume \\
\hline Phusion ${ }^{\circledR}$ Hot Start Flex $2 \mathrm{X}$ & $12.5 \mu \mathrm{l}$ \\
Master Mixart version & \\
Forward primer $(1 \mu \mathrm{M})$ & $2.5 \mu \mathrm{l}$ \\
Reverse primer $(1 \mu \mathrm{M})$ & $2.5 \mu \mathrm{l}$ \\
Template DNA & $50 \mathrm{ng}$ \\
\hline
\end{tabular}

PCR, polymerase chain reaction.

antibody (diluted at 1:10,000) for $1 \mathrm{~h}$ at room temperature. After exposure, the film was scanned and the molecular weight and optical density of the target band were analyzed by Image J processing system.

Flow cytometry. Flow cytometry was adopted to determine the percentages of CD40, CD80, CD204 and CD206 as macrophage surface antigens. First, the four KC groups were cultured for $12 \mathrm{~h}$ and washed with PBS once to collect $1 \times 10^{6}$ adherent cells into flow cytometry tubes. Next, the collected cells were rinsed with 1-ml PBS twice and re-suspended with $200-\mu 1$ PBS. Then KCs were incubated with FITC-labeled CD40 antibody, CD80 antibody, CD204 antibody and CD206 antibody at $4^{\circ} \mathrm{C}$ for $30 \mathrm{~min}$. After washed 3 times with $1-\mathrm{ml}$ PBS, the cells were centrifuged at $1,038 \times \mathrm{g}$ at $4^{\circ} \mathrm{C}$ for $5 \mathrm{~min}$, washed, and re-suspended with 200- $\mu$ 1 PBS to detect CD40, CD80, CD204 and CD206 with BD FACSARIA II Flow Cytometer of Becton-Dickinson and Company (BD). The detection results were analyzed with Flowjo in percentage.

Liver function test. The levels of alanine aminotransferase (ALT), aspartate aminotransferase (AST) and $\gamma$-glutamyltranspeptidase $(\gamma-\mathrm{GT})$ in mice were measured as indicators to evaluate liver function. Four indicators of liver fibrosis in serum were tested to assess the degree of fibrosis in the liver, including concentration of PIIINP, IVC, LN and HA.

Statistical analysis. SPSS V.24.0.0 was used for statistical analysis. All the data followed a normal distribution. One-way ANOVA was used for comparison of multiple groups. The Bonferroni test was preferred for pairwise comparison, whereas the t-test for comparison of means of two independent 

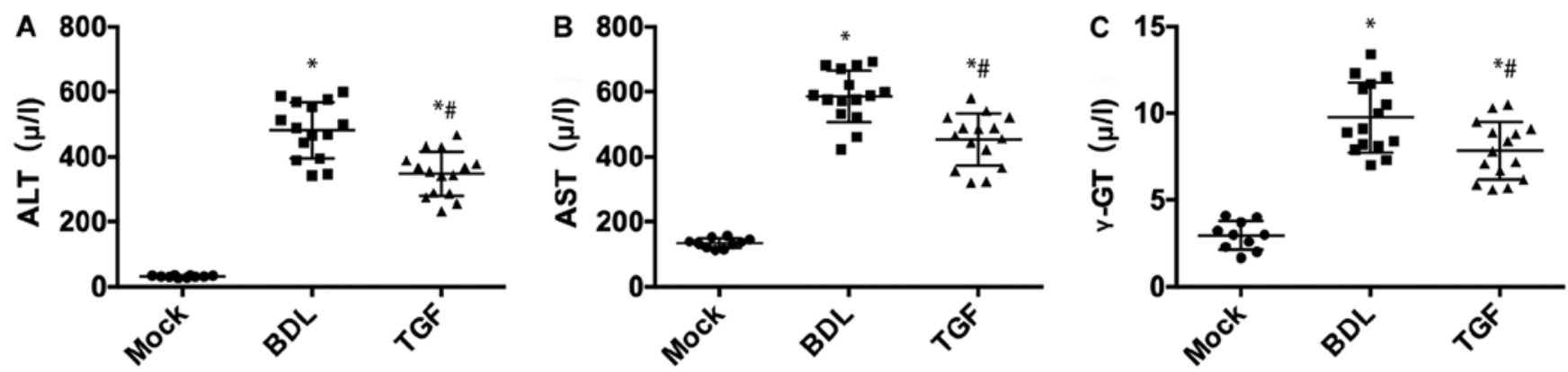

Figure 1. Effects of TGF- $\beta 1$ on (A) ALT, (B) AST and (C) $\gamma$-GT in cholestatic mice. Mock group $(\mathrm{n}=10)$ underwent a sham operation. BDL group (n=15) had bile duct ligated. TGF group $(\mathrm{n}=15)$ was injected with TGF- $\beta 1$ after bile duct ligation. ${ }^{*} \mathrm{P}<0.05$ compared with Mock group; ${ }^{*} \mathrm{P}<0.05$ compared with $\mathrm{BDL}$ group. TGF- $\beta 1$, transforming growth factor- $\beta 1$; ALT, alanine aminotransferase; AST, aspartate aminotransferase; $\gamma$-GT, $\gamma$-glutamyltranspeptidase; BDL, bile duct ligation.

groups. The difference obtained was statistically significant at $\mathrm{P}<0.05$.

\section{Results}

TGF- $\beta 1$ improves liver function in cholestatic mice. Compared with Mock group, mice in the BDL group had significant increase in ALT and AST $(\mathrm{P}<0.05)$ but there was significant decrease in ALT and AST in the TGF group $(\mathrm{P}<0.05)$ (Fig. 1), which indicated that BDL caused severe hepatocyte injury while TGF could mitigate the injury. Besides, $\gamma$-GT was significantly higher in BDL group than that in Mock group and TGF group (Fig. 1), suggesting that BDL was accompanied by cholestasis, whereas TGF relieved this lesion. In addition, the results of liver fibrosis, PIIINP, IVC, LN and HA in mouse serum are shown in Table I. Compared with the Mock group, the degree of liver fibrosis of the BDL group and the TGF group was significantly increased, and the degree of the BDL group was significantly higher than that in the TGF group (Table III). Thus it was considered that TGF ameliorated noticeably hepatocyte injury, cholestasis and degree of liver fibrosis in mice.

TGF- $\beta 1$ decreases expression of inflammatory cytokines in cholestatic mice. As shown in Fig. 2, the levels of inflammatory cytokines, IL- $1 \beta$, IL- 6 and TNF- $\alpha$, in BDL group were significantly increased in comparison to Mock group $(\mathrm{P}<0.05)$ and TGF group $(\mathrm{P}<0.05)$. The outcomes also included $\mathrm{NF}-\kappa \mathrm{B}$ in hepatocytes, which were expressed significantly higher in BDL group than that in Mock group and TGF group $(\mathrm{P}<0.05)$. In this study, the expression level of IL-10 in the liver of mice was measured. As shown in Fig. 3, the liver cells of mice in the BDL group and the Mock group secreted only a small amount of IL-10, while the level of IL-10 in the TGF group increased significantly. This showed the alleviation of TGF in liver inflammation in cholestatic mice.

TGF- $\beta 1$ induces M2 transformation of KCs in cholestatic mice. The protein expression of macrophage-specific markers in isolated KCs shown in the results, the expression of iNOS and Arg-1 significantly increased in BDL group, where iNOS was more expressed than Arg-1 $(\mathrm{P}<0.05)$, compared with that of Mock group. The TGF group had significantly lower iNOS protein expression and Arg-1 was significantly higher than those in BDL group $(\mathrm{P}<0.05)$. iNOS protein is an $\mathrm{M} 1$ macrophage-specific marker, while Arg-1 protein is M2
Table III. Percentages of surface antigens in KCs in each group.

\begin{tabular}{lccc}
\hline Molecule & $\begin{array}{c}\text { Control } \\
\text { group (\%) }\end{array}$ & $\begin{array}{c}\text { LPS } \\
\text { group (\%) }\end{array}$ & $\begin{array}{c}\text { TGF } \\
\text { group (\%) }\end{array}$ \\
\hline CD40 & $33.29 \pm 4.852$ & $73.86 \pm 6.674^{\mathrm{a}}$ & $51.67 \pm 5.845^{\mathrm{b}}$ \\
CD86 & $19.43 \pm 3.586$ & $85.84 \pm 4.684^{\mathrm{a}}$ & $53.66 \pm 5.075^{\mathrm{b}}$ \\
CD204 & $13.60 \pm 2.821$ & $29.25 \pm 4.375^{\mathrm{a}}$ & $47.23 \pm 7.826^{\mathrm{b}}$ \\
CD206 & $12.21 \pm 2.557$ & $28.20 \pm 4.889^{\mathrm{a}}$ & $53.27 \pm 7.109^{\mathrm{b}}$
\end{tabular}

${ }^{\mathrm{a}} \mathrm{P}<0.05$ compared with control group; ${ }^{\mathrm{b}} \mathrm{P}<0.05$ compared with LPS group. KCs, Kupffer cells; TGF, transforming growth factor.

macrophage-specific, so it can be concluded that TGF treatment could induce $\mathrm{KCs}$ in cholestatic mice to transform from M1 to M2 (Fig. 4).

TGF- $\beta 1$ downregulates expression of LPS-activated inflammatory cytokines in KCs. Real-time PCR showed that the relative mRNA expression of IL-1 $\beta$, IL- 6 and TNF- $\alpha$ were significantly lower in TGF group treated with LPS and TGF than those in mice treated with LPS alone $(\mathrm{P}<0.05)$ and in Galunisertib group $(\mathrm{P}<0.05)$, but there was no significant change between Galunisertib group and LPS group (P>0.05) (Fig. 5). Fig. 6 illustrates that NF- $\kappa$ B expression was significantly lower in TGF group by contrast with LPS group which had no significant difference from Galunisertib group. TGF downregulated NF- $\kappa \mathrm{B}$ pathways in $\mathrm{KCs}$, and NF- $\mathrm{NB}$ was a participant and important player in inflammatory responses. Kupffer cells in the control group, LPS group, and inhibitor group secreted only a small amount of IL-10, while Kupffer cells in the TGF group secreted more IL-10 (Fig. 7). TGF was hereby demonstrated to be anti-inflammatory as it downregulated the inflammatory pathway and inflammatory cytokines in $\mathrm{KCs}$.

TGF- $\beta 1$ induces LPS-activated KCs to transform into M2. Flow cytometry was adopted to determine the percentages of CD40, CD80, CD204 and CD206. As seen in Table III, as M1 macrophage-specific surface antigens, CD40 and CD86 were in significantly higher percentages in LPS group than those in control group and TGF group $(\mathrm{P}<0.05)$, while the TGF group had the CD204 and CD206 on M2 macrophage 
A
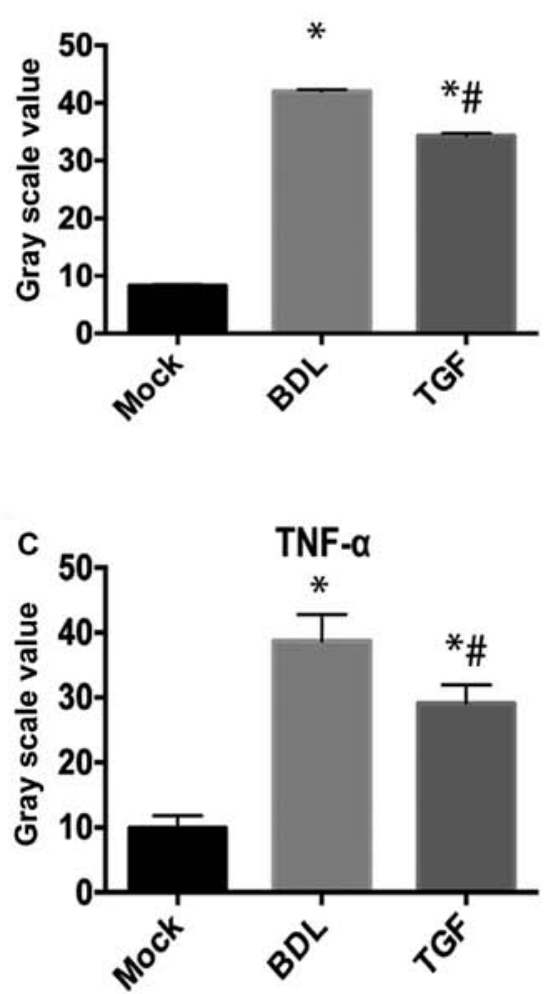

B IL-6

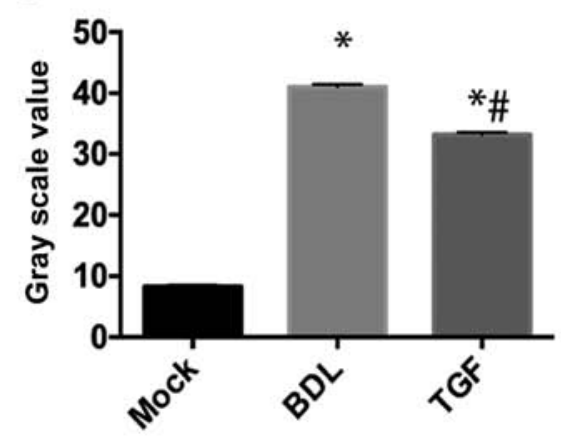

D

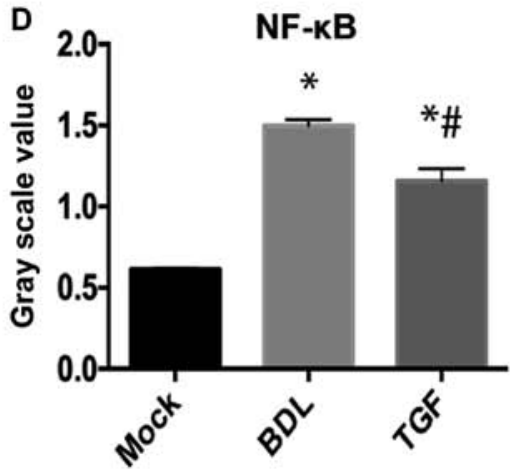

E

BDL

BDL+TGF

Mock

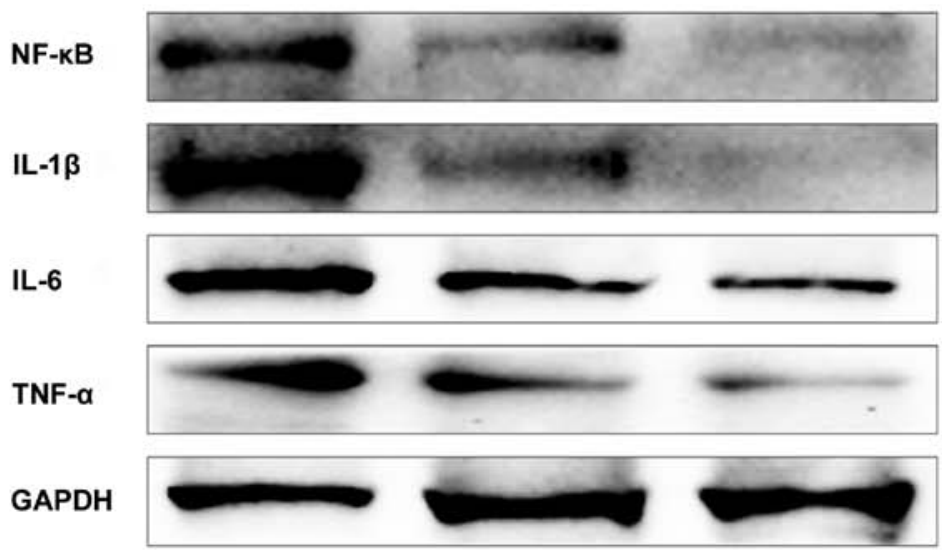

Figure 2. Expression of (A) IL-1 $\beta$, (B) IL-6, (C) TNF- $\alpha$ and (D) NF- $\kappa$ B in hepatocytes of each group, detected by (E) western blotting. * $\mathrm{P}<0.05$ compared with Mock group; ${ }^{\#} \mathrm{P}<0.05$ compared with BDL group. IL, interleukin; TNF- $\alpha$, tumor necrosis factor- $\alpha$; NF- $\kappa \mathrm{B}$, nuclear factor- $\kappa \mathrm{B}$; BDL, bile duct ligation.
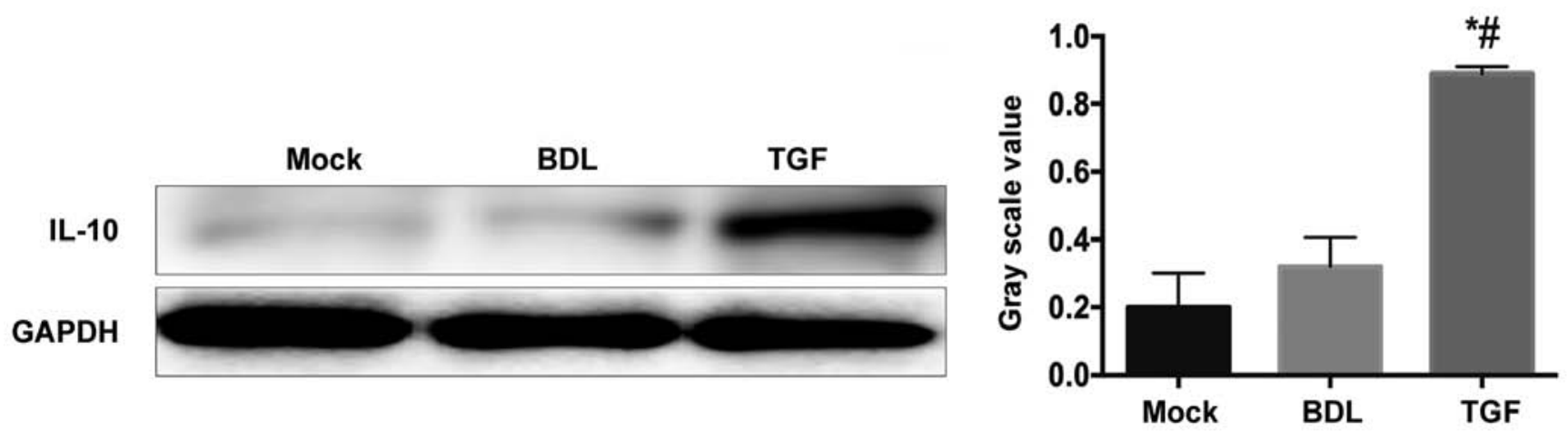

Figure 3. IL-10 protein expression level in liver cells of mice in each group. ${ }^{*} \mathrm{P}<0.05$ compared with the Mock group; ${ }^{*} \mathrm{P}<0.05$ compared with the BDL group. IL, interleukin. 
A
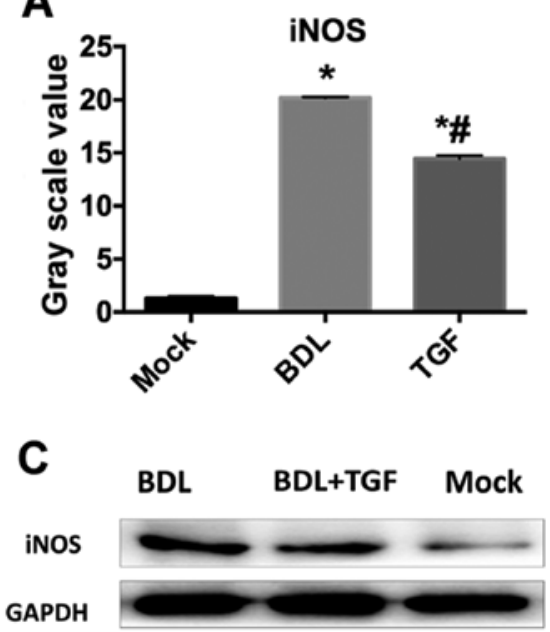

B

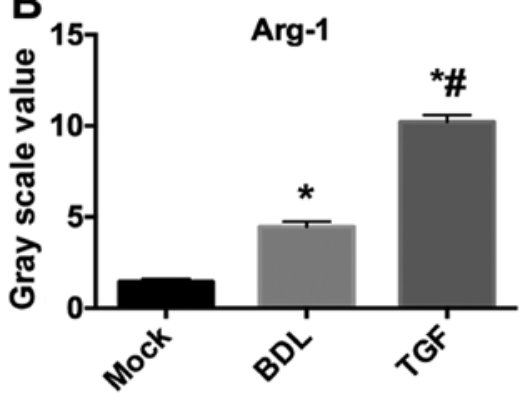

BDL

BDL+TGF Mock

Arg-1

GAPDH

Figure 4. Protein expressions of (A) iNOS and (B) Arg-1 in KCs in each group, detected by (C) western blotting. " $\mathrm{P}<0.05$ compared with Mock group; ${ }^{*} \mathrm{P}<0.05$ compared with BDL group. iNOS, inducible nitric oxide synthase; Arg-1, arginase-1; KCs, Kupffer cells; BDL, bile duct ligation.

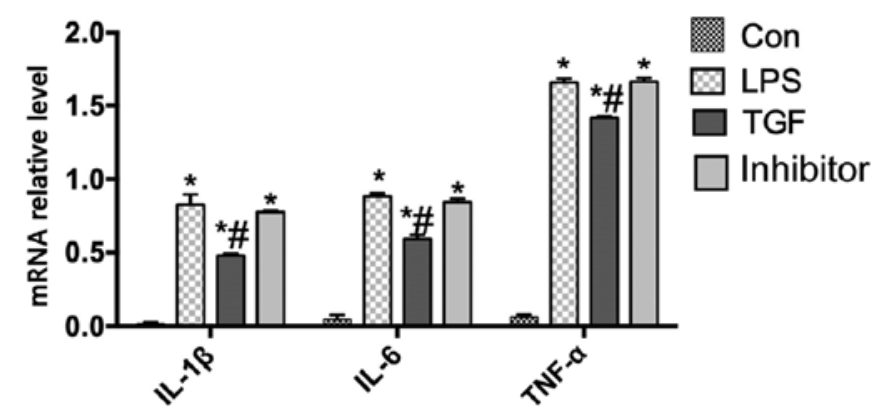

Figure 5. Relative mRNA expression of IL-1 $\beta$, IL-6 and TNF- $\alpha$ in KCs in each group. Compared to the control group, LPS group was treated with $100 \mathrm{ng} / \mathrm{ml}$ LPS for $12 \mathrm{~h}$; TGF group was pretreated with $10 \mathrm{ng} / \mathrm{ml}$ TGF for $3 \mathrm{~h}$, then stimulated with $100 \mathrm{ng} / \mathrm{ml}$ LPS, and cultured for $12 \mathrm{~h}$. Inhibitor group was pretreated with $10 \mu \mathrm{M}$ Galunisertib and $10 \mathrm{ng} / \mathrm{ml} \mathrm{TGF}$ for $3 \mathrm{~h}$, and then cultured with $100 \mathrm{ng} / \mathrm{ml}$ LPS for $12 \mathrm{~h}$. "P<0.05 compared with the control group; ${ }^{*} \mathrm{P}<0.05$ compared with LPS group. IL, interleukin; TNF- $\alpha$, tumor necrosis factor- $\alpha$; KCs, Kupffer cells.
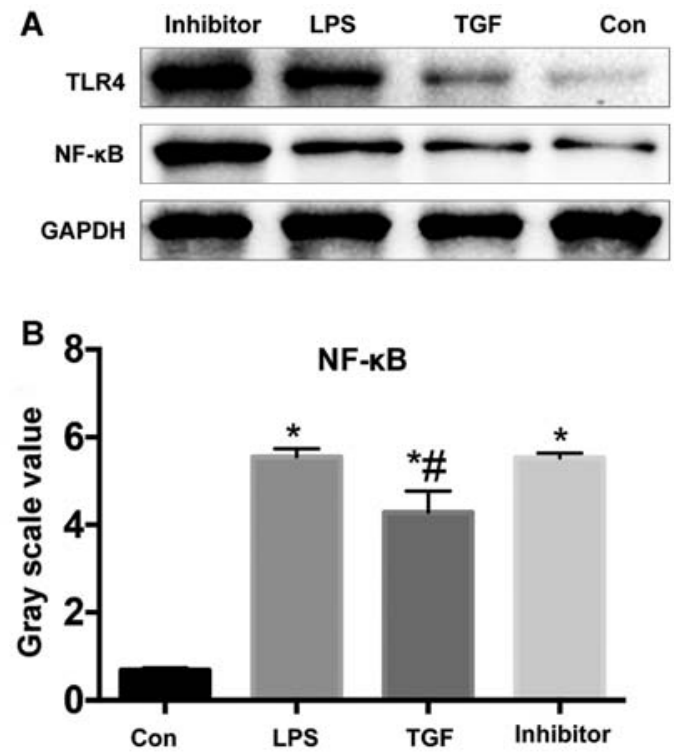

Figure 6. Protein expression of NF- $\kappa \mathrm{B}$ in KCs in each group. (A) protein expression. (B) Western blot figure. ${ }^{*} \mathrm{P}<0.05$ compared with control group; ${ }^{\#} \mathrm{P}<0.05$

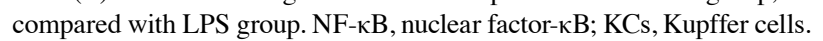

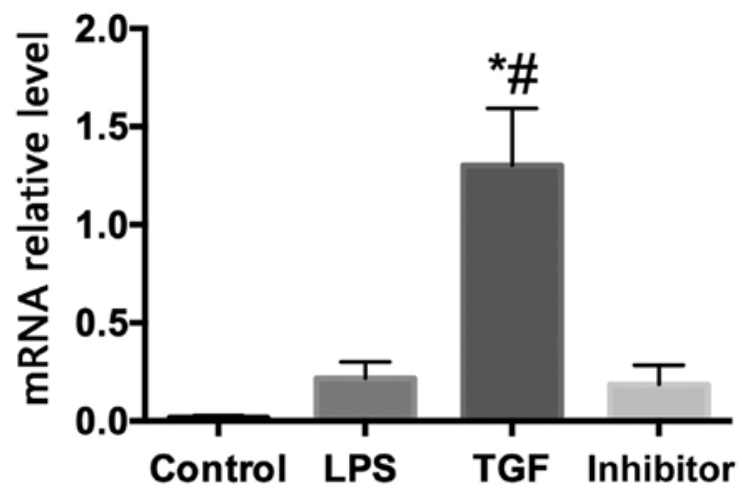

Figure 7. Relative expression of IL-10 mRNA in Kupffer cells. control group, blank control group; LPS group, Kupffer cells were treated with $100 \mathrm{ng} / \mathrm{ml}$ LPS; TGF group, Kupffer cells were pretreated with $10 \mathrm{ng} / \mathrm{ml} \mathrm{TGF}$ for $3 \mathrm{~h}$, then $100 \mathrm{ng} / \mathrm{ml}$ LPS was added to stimulate KCs, to culture for $12 \mathrm{~h}$; Galunisertib group, Kupffer cells were pretreated with $10 \mu \mathrm{M}$ Galunisertib inhibitor and $10 \mathrm{ng} / \mathrm{ml}$ TGF for $3 \mathrm{~h}$, and then $100 \mathrm{ng} / \mathrm{ml}$ LPS was added to culture KCs for $12 \mathrm{~h}$. " $\mathrm{P}<0.05$ compared with the control group; ${ }^{\prime} \mathrm{P}<0.05$ compared with the LPS group. IL, interleukin; TGF- $\beta 1$, transforming growth factor- $\beta 1$; KCs, Kupffer cells.

surfaces at a significantly higher level compared with those in the other two groups $(\mathrm{P}<0.05)$. Fig. 8 shows that iNOS protein expression was significantly higher in LPS group than that in control group and TGF group, whereas Arg-1 protein expression was significantly lower in comparison to TGF group. It indicated that TGF induced M2 transformation of LPS-activated KCs.

\section{Discussion}

Cholestasis, a multi-etiological clinical syndrome, has gradually developed into one of the major health concerns (28-30), so new targets need to be found urgently in clinic.

TGF- $\beta 1$ is a key player in various normal physiological and pathological processes. It regulates macrophage apoptosis induced by low serum concentration $(26,31,32)$, and effectively inhibits the occurrence of macrophage inflammatory response as macrophages mature. 

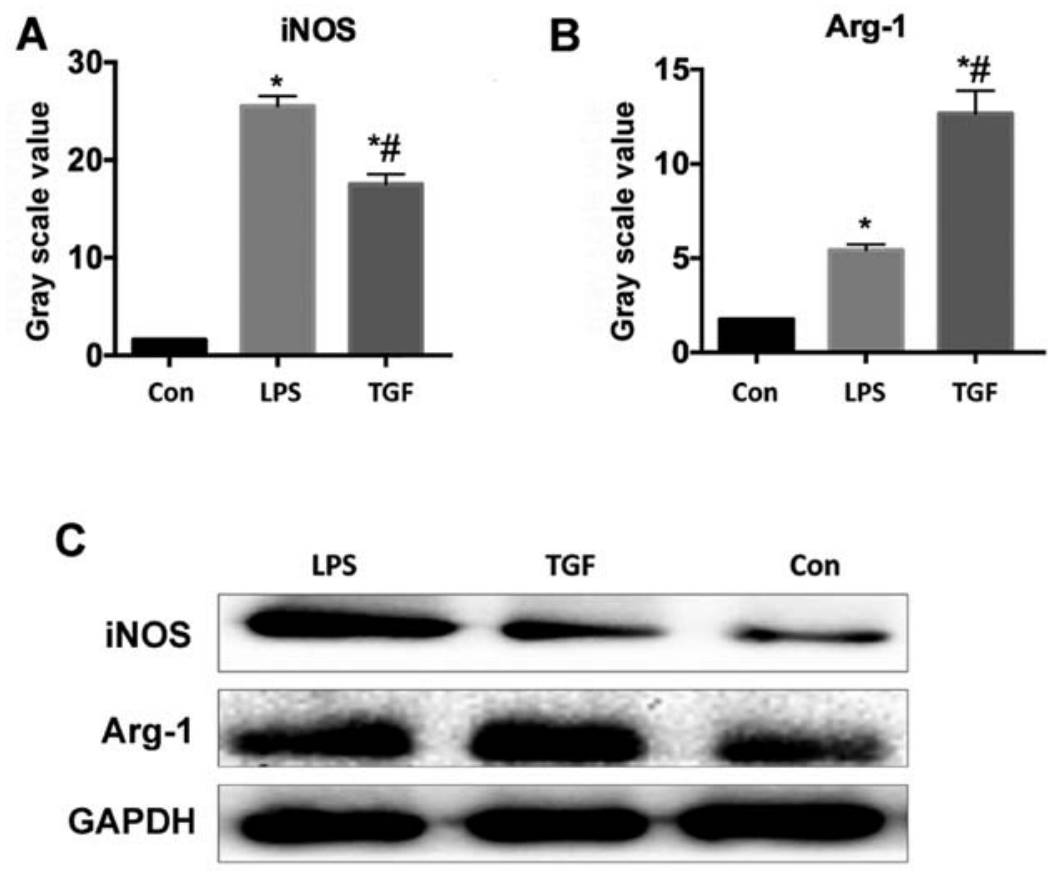

Figure 8. Protein expression of iNOS and Arg-1 in KCs in each group. (A) Protein expression of iNOS. (B) Protein expression of Arg-1. (C) Western blot figure. "P<0.05 compared with control group; ${ }^{"} \mathrm{P}<0.05$ compared with LPS group. iNOS, inducible nitric oxide synthase; Arg-1, arginase-1; KCs, Kupffer cells.

Liver function test is widely used to detect liver condition in terms of ALT and AST, transaminase in hepatocytes and to indicate liver injury (33). Serum $\gamma$-GT is an indicator of biliary obstruction and hepatitis activity (34). Bile duct ligation (BDL), is the most common model used to induce cholestatic fibrosis in rodents $(35,36)$. The results showed that AST and ALT in mice that underwent BDL increased significantly, indicating hepatocyte necrosis, while increased $\gamma$-GT indicated cholestasis. However, mice injected with TGF- $\beta 1$ had significantly mitigated hepatocyte injury, which suggested that TGF- $\beta 1$ might relieve liver injury and cholestasis.

It was found that the injection of TGF- $\beta 1$ suppressed the nuclear factor $\kappa$-light-chain-enhancer of activated B cells $(\mathrm{NF}-\kappa \mathrm{B})$ pathway in the liver and significantly reduced the expression of IL- $1 \beta$, IL-6, TNF- $\alpha$ in mice receiving BDL with real-time PCR and the western blot analysis. NF- $\kappa$ B may cause severe inflammation under abnormal conditions (37). It is generally expressed in cytoplasm of almost all cell types (38). $\mathrm{NF}-\mathrm{KB}$ binding activity is normally absent in stable binding to $\mathrm{I} \kappa \mathrm{B}$, but in case of external stimulation, the cell surface is activated, regulating the immune response of target genes to produce inflammatory cytokines $(39,40)$ such as IL-6, IL-1 and TNF- $\alpha$. TGF- $\beta 1$, as an anti-inflammatory cytokine, effectively inhibits NF- $\kappa B$ pathway in BDL mice. Macrophages are released and activated in the portal area of PBC patients to release a large amount of inflammatory cytokines, such as TNF- $\alpha$, IL- $1 \beta$ and IL- 6 , causing cascade inflammatory cytokine responses and severe liver injury (41). The western blot analysis concluded in this study that treating BDL mice with TGF- $\beta 1$ reduced the expression of IL- $1 \beta$, IL- 6 and TNF- $\alpha$, members of pro-inflammatory cytokines of which the latter two were linked to oxygen-radical-mediated liver injury and thus cholestatic hepatitis in recent studies (42). It suggests that they play critical roles in the formation of acute intrahepatic cholestasis (43). Expression of IL-1 $\beta$, IL-6, and TNF- $\alpha$ were significantly increased in LPS group pretreated with TGF- $\beta 1$ in comparison to LPS group. Galunisertib is a TGF- $\beta 1$ receptor inhibitor used to determine changes in the study target TGF- $\beta 1$, and the results indicate that they returned to the levels following LPS treatment after the mice were administered TGF- $\beta 1$ inhibitor Galunisertib, showing that TGF- $\beta 1$ protected the inflammatory response of KCs. Hence, TGF- $\beta 1$ inhibited the production of inflammatory cytokines, and downregulated the expression of upstream regulatory proteins, thus alleviating liver injury caused by inflammatory responses.

$\mathrm{KCs}$ are the main source of pro-inflammatory cytokines in the liver (44-46). Intestinal LPS has been observed to promote the pro-inflammatory response of liver macrophages, resulting in increased transcription of bile acid and bilirubin and cholestatic hepatocellular injury initiated by bile acid accumulation in the liver (47). Activation of NF- $\mathrm{kB}$ pathway in KCs is accompanied by high amounts of pro-inflammatory cytokines, thus aggravating the inflammatory response in the liver, while increased release of IL-10 by KCs reduces inflammation. The difference is caused by different phenotypes of KCs. Macrophages secrete enzymes and cytokines to produce anti-inflammation, promote tissue repair and angiogenesis, and regulate immune responses; these secreted cytokines further affect the polarization state of macrophages (48-50). $\mathrm{KCs}$ is mainly grouped into two significantly different types: classically activated M1 KCs and alternatively activated M2 KCs. iNOS is recognized in considerable number of studies as a specific expression marker of M1 macrophages, whereas, Found in Inflammatory Zone 1 (FIZZ1), arginase-1 (Arg-1) and IL-10 are those of M2 macrophages $(51,52)$. In both the animal trial and cell trial, TGF- $\beta 1$ treatment was observed to elevate the expression of M2-specific ARG-1 and the percentages of surface antigens CD203 and CD206, but lower the expression of M1-specific iNOS and the percentages of CD40 and CD86, which indicated that TGF- $\beta 1$ treatment 
could induce M2 transformation of macrophages in cholestatic mice. M1 macrophages are crucial in inflammatory responses, pathogen clearance and antitumor immunity, while by secreting cytokines such as IL-10, M2 is anti-inflammatory, inhibiting immune responses, and parasite clearance and angiogenesis (53). The above-mentioned trials confirmed that TGF- $\beta 1$ promoted the differentiation of macrophages into M2, but the specific mechanism remains unknown.

This study was a preliminarily confirmation that TGF- $\beta 1$ interfered with the activation of NF- $\mathrm{\kappa B}$ signal transduction pathway in macrophages and the expression of IL-1 $1 \beta$, IL- 6 and TNF- $\alpha$, thus suppressing the inflammatory responses of cholestatic hepatitis. It provided laboratory basis for clinical use of TGF drugs in treatment of cholestatic hepatitis.

\section{Acknowledgements}

Not applicable.

\section{Funding}

Project Funded by National Natural Science Foundation of China (81700537), Major Project of Changzhou Health and Family Planning Commission (ZD201606).

\section{Availability of data and materials}

The datasets used and/or analyzed during the current study are available from the corresponding author on reasonable request.

\section{Authors' contributions}

JQ, YJ, HL and HY led the conception and design of this study. JQ, GW, XC and HY were responsible for the data collection and analysis. YJ, GW and $\mathrm{HY}$ were in charge of interpreting the data and drafting the manuscript. JQ and YJ made revision from critical perspective for important intellectual content. The final version was read and adopted by all the authors.

\section{Ethics approval and consent to participate}

The study was approved by the Ethics Committee of The Affiliated Changzhou No. 2 People's Hospital of Nanjing Medical University (Changzhou, China).

\section{Patient consent for publication}

Not applicable.

\section{Competing interests}

The authors declare that they have no competing interests.

\section{References}

1. Zakharia K, Tabibian A, Lindor KD and Tabibian JH: Complications, symptoms, quality of life and pregnancy in cholestatic liver disease. Liver Int 38: 399-411, 2018

2. Zhao S, Li N, Zhen Y, Ge M, Li Y, Yu B, He H and Shao RG: Protective effect of gastrodin on bile duct ligation-induced hepatic fibrosis in rats. Food Chem Toxicol 86: 202-207, 2015.
3. Seca AM and Pinto DC: Plant secondary metabolites as anticancer agents: Successes in clinical trials and therapeutic application. Int J Mol Sci 19: 19, 2018.

4. Miyaguchi S, Ebinuma H, Imaeda H, Nitta Y, Watanabe T, Saito $\mathrm{H}$ and Ishii $\mathrm{H}$ : A novel treatment for refractory primary biliary cirrhosis? Hepatogastroenterology 47: 1518-1521, 2000.

5. Drivdal M, Holven KB, Retterstøl K, Aagenaes $\emptyset$ and Kase BF: A nine year follow-up study of patients with lymphoedema cholestasis syndrome 1 (LCS1/Aagenaes syndrome). Scand J Clin Lab Invest 78: 566-574, 2018.

6. Paquissi FC: Immunity and fibrogenesis: The role of Th17/IL-17 axis in HBV and HCV-induced chronic hepatitis and progression to cirrhosis. Front Immunol 8: 1195, 2017.

7. Burnevich ES, Popova EN, Ponomarev AB, Nekrasova TP, Lebedeva MV, Filatova AL, Shchanitcyna EM, Ponomareva LA, Beketov VD, Bondarenko IB, et al: Autoimmune liver disease (primary biliary cholangitis/autoimmune hepatitis-overlap) associated with sarcoidosis (clinical cases and literature review). Ter Arkh 91: 89-94, 2019.

8. Zhu J, Wang R, Xu T, Zhang S, Zhao Y, Li Z, Wang C, Zhou J, Gao D, Hu Y, et al: Salvianolic acid a attenuates endoplasmic reticulum stress and protects against cholestasis-induced liver fibrosis via the SIRT1/HSF1 pathway. Front Pharmacol 9: 1277, 2018.

9. Mohammadi A, Blesso CN, Barreto GE, Banach M, Majeed M and Sahebkar A: Macrophage plasticity, polarization and function in response to curcumin, a diet-derived polyphenol, as an immunomodulatory agent. J Nutr Biochem 66: 1-16, 2019.

10. Cheng Z, Zhou YZ, Wu Y, Wu QY, Liao XB, Fu XM and Zhou XM: Diverse roles of macrophage polarization in aortic aneurysm: Destruction and repair. J Transl Med 16: 354, 2018

11. Sica A, Erreni M, Allavena P and Porta C: Macrophage polarization in pathology. Cell Mol Life Sci 72: 4111-4126, 2015.

12. Gong W, Huang F, Sun L, Yu A, Zhang X, Xu Y, Shen Y and Cao J: Toll-like receptor-2 regulates macrophage polarization induced by excretory-secretory antigens from Schistosoma japonicum eggs and promotes liver pathology in murine schistosomiasis. PLoS Negl Trop Dis: Dec 27, 2018 (Epub ahead of print). doi: 10.1371/journal.pntd.0007000.

13. Cho U, Kim B, Kim S, Han Y and Song YS: Pro-inflammatory M1 macrophage enhances metastatic potential of ovarian cancer cells through NF- $\mathrm{KB}$ activation. Mol Carcinog 57: 235-242, 2018.

14. Wang Y, Smith W, Hao D, He B and Kong L: M1 and M2 macrophage polarization and potentially therapeutic naturally occurring compounds. Int Immunopharmacol 70: 459-466, 2019.

15. Qing L, Fu J, Wu P, Zhou Z, Yu F and Tang J: Metformin induces the M2 macrophage polarization to accelerate the wound healing via regulating AMPK/mTOR/NLRP3 inflammasome singling pathway. Am J Transl Res 11: 655-668, 2019.

16. Wang Y, Guo X, Jiao G, Luo L, Zhou L, Zhang J and Wang B: Splenectomy promotes macrophage polarization in a mouse model of concanavalin A- (ConA-) induced liver fibrosis. BioMed Res Int 2019: 5756189, 2019.

17. Lu CH, Lai CY, Yeh DW, Liu YL, Su YW, Hsu LC, Chang CH, Catherine Jin SL and Chuang TH: Involvement of M1 macrophage polarization in endosomal Toll-like receptors activated psoriatic inflammation. Mediators Inflamm: Dec 16, 2018 (Epub ahead of print). doi: $10.1155 / 2018 / 3523642$.

18. Tsuneyama K, Harada K, Kono N, Hiramatsu K, Zen Y, Sudo Y, Gershwin ME, Ikemoto M, Arai H and Nakanuma Y: Scavenger cells with gram-positive bacterial lipoteichoic acid infiltrate around the damaged interlobular bile ducts of primary biliary cirrhosis. J Hepatol 35: 156-163, 2001

19. Prunier C, Baker D, Ten Dijke P and Ritsma L: TGF- $\beta$ family signaling pathways in cellular dormancy. Trends Cancer 5: 66-78, 2019.

20. Dragotto J, Canterini S, Del Porto P, Bevilacqua A and Fiorenza MT: The interplay between TGF- $\beta$-stimulated TSC 22 domain family proteins regulates cell-cycle dynamics in medulloblastoma cells. J Cell Physiol 234: 18349-18360, 2019.

21. Derynck R and Budi EH: Specificity, versatility, and control of TGF- $\beta$ family signaling. Sci Signal 12: 12, 2019.

22. Dropmann A, Dediulia T, Breitkopf-Heinlein K, Korhonen H, Janicot M, Weber SN, Thomas M, Piiper A, Bertran E, Fabregat I, et al: TGF- $\beta 1$ and TGF- $\beta 2$ abundance in liver diseases of mice and men. Oncotarget 7: 19499-19518, 2016.

23. Li MO, Wan YY, Sanjabi S, Robertson AK and Flavell RA: Transforming growth factor-beta regulation of immune responses. Annu Rev Immunol 24: 99-146, 2006. 
24. Kim KK, Sheppard D and Chapman HA: TGF- $\beta 1$ signaling and tissue fibrosis. Cold Spring Harb Perspect Biol 10: 10, 2018.

25. Tang J, Gifford CC, Samarakoon R and Higgins PJ: Deregulation of negative controls on TGF- $\beta 1$ signaling in tumor progression. Cancers (Basel) 10: 10, 2018.

26. Zeng WQ, Zhang JQ, Li Y, Yang K, Chen YP and Liu ZJ: A new method to isolate and culture rat kupffer cells. PLoS One 8: e70832, 2013.

27. Mishra B, Tang Y, Katuri V, Fleury T, Said AH, Rashid A, Jogunoori W and Mishra L: Loss of cooperative function of transforming growth factor-beta signaling proteins, smad3 with embryonic liver fodrin, a beta-spectrin, in primary biliary cirrhosis. Liver Int 24: 637-645, 2004.

28. Neuman M, Angulo P, Malkiewicz I, Jorgensen R, Shear N, Dickson ER, Haber J, Katz G and Lindor K: Tumor necrosis factor-alpha and transforming growth factor-beta reflect severity of liver damage in primary biliary cirrhosis. J Gastroenterol Hepatol 17: 196-202, 2002.

29. Martinez OM, Villanueva JC, Gershwin ME and Krams SM Cytokine patterns and cytotoxic mediators in primary biliary cirrhosis. Hepatology 21: 113-119, 1995.

30. Liu B, Zhang X, Zhang FC, Zong JB, Zhang W and Zhao Y: Aberrant TGF- $\beta 1$ signaling contributes to the development of primary biliary cirrhosis in murine model. World J Gastroenterol 19: 5828-5836, 2013.

31. Hasan MS, Karim AB, Rukunuzzaman M, Haque A, Akhter MA, Shoma UK, Yasmin F, Rahman MA and Rahman MA: Role of liver biopsy in the diagnosis of neonatal cholestasis due to biliary atresia. Mymensingh Med J 27: 826-833, 2018.

32. Houwen R: Chapter 6.4. Diagnostic Progress in Cholestasis J Pediatr Gastroenterol Nutr 66 (Suppl 1): S134-S136, 2018

33. Trauner M, Meier PJ and Boyer JL: Molecular pathogenesis of cholestasis. N Engl J Med 339: 1217-1227, 1998.

34. Virani S, Akers A, Stephenson K, Smith S, Kennedy L, Alpini G and Francis $\mathrm{H}$ : Comprehensive review of molecular mechanisms during cholestatic liver injury and cholangiocarcinoma. J Liver 7: 7,2018.

35. Cies JJ and Giamalis JN: Treatment of cholestatic pruritus in children. Am J Health Syst Pharm 64: 1157-1162, 2007.

36. Hirschfield GM and Heathcote EJ: Cholestasis and cholestatic syndromes. Curr Opin Gastroenterol 25: 175-179, 2009.

37. Sun X, Xie Z, Ma Y, Pan X, Wang J, Chen Z and Shi P: TGF- $\beta$ inhibits osteogenesis by upregulating the expression of ubiquitin ligase SMURF1 via MAPK-ERK signaling. J Cell Physiol 233: 596-606, 2018

38. Hu B, Xu C, Cao P, Tian Y, Zhang Y, Shi C, Xu J, Yuan W and Chen H: TGF- $\beta$ stimulates expression of chondroitin polymerizing factor in nucleus pulposus cells through the Smad3, RhoA/ ROCK1, and MAPK signaling pathways. J Cell Biochem 119: 566-579, 2018

39. Du M, Chen W, Zhang W, Tian XK, Wang T, Wu J, Gu J, Zhang N, Lu ZW, Qian LX, et al: TGF- $\beta 1$ regulates the ERK/MAPK pathway independent of the SMAD pathway by repressing miRNA-124 to increase MALAT1 expression in nasopharyngeal carcinoma. Biomed Pharmacother 99: 688-696, 2018.

40. Coppola N, Zampino R, Sagnelli C, Bellini G, Marrone A, Stanzione M, Capoluongo N, Boemio A, Minichini C, Adinolfi LE, et al: Cannabinoid receptor 2-63 QQ variant is associated with persistently normal aminotransferase serum levels in chronic hepatitis C. PLoS One 9: e99450, 2014.
41. Mazzella G, Salzetta A, Casanova S, Morelli MC, Villanova N, Miniero R, Sottili S, Novelli V, Cipolla A, Festi D, et al: Treatment of chronic sporadic-type non-A, non-B hepatitis with lymphoblastoid interferon: Gamma GT levels predictive for response. Dig Dis Sci 39: 866-870, 1994.

42. Van Campenhout S, Van Vlierberghe H and Devisscher L: Common bile duct ligation as model for secondary biliary cirrhosis. Methods Mol Biol 1981: 237-247, 2019.

43. Lotowska JM, Sobaniec-Lotowska ME, Lebensztejn DM, Daniluk U, Sobaniec P, Sendrowski K, Daniluk J, Reszec J, Debek W, Festi D, et al: Ultrastructural characteristics of rat hepatic oval cells and their intercellular contacts in the model of biliary fibrosis: New insights into experimental liver fibrogenesis. Gastroenterol Res Pract 2017: 2721547, 2017.

44. Liu TZ, Lee KT, Chern CL, Cheng JT, Stern A and Tsai LY: Free radical-triggered hepatic injury of experimental obstructive jaundice of rats involves overproduction of proinflammatory cytokines and enhanced activation of nuclear factor kappaB. Ann Clin Lab Sci 31: 383-390, 2001

45. Huang ZH, Huang X and Li Y: Changes and significance of tumor necrosis factor-alpha and interleukin-6 level in plasma and bile during the formation of acute intrahepatic cholestasis in New Zealand white rabbits. Zhonghua Gan Zang Bing Za Zhi 11: 313 , 2003 (In Chinese).

46. Sen R and Baltimore D: Inducibility of kappa immunoglobulin enhancer-binding protein NF-kappaB by a posttranslational mechanism. Cell 47: 921-928, 1986.

47. Ghosh S and Hayden MS: New regulators of NF-kappaB in inflammation. Nat Rev Immunol 8: 837-848, 2008.

48. Editors PO; PLOS ONE Editors: Expression of Concern: The interplay between NF-kappaB and $\mathrm{E} 2 \mathrm{~F} 1$ coordinately regulates inflammation and metabolism in human cardiac cells. PLoS One 14: e0216434, 2019.

49. Park J, Ha SH, Abekura F, Lim H, Magae J, Ha KT, Chung TW, Chang YC, Lee YC, Chung E, et al: 4-O-carboxymethyl ascochlorin inhibits expression levels of on inflammation-related cytokines and matrix metalloproteinase-9 through NF- $\kappa B /$ MAPK/TLR4 signaling pathway in LPS-activated RAW264.7 cells. Front Pharmacol 10: 304, 2019.

50. van der Tuin SJ, Li Z, Berbée JF, Verkouter I, Ringnalda LE, Neele AE, van Klinken JB, Rensen SS, Fu J, de Winther MP, et al: Lipopolysaccharide lowers cholesteryl ester transfer protein by activating F4/80+Clec4f+Vsig4+Ly6C- Kupffer cell subsets. J Am Heart Assoc 7: 7, 2018.

51. Feng P, Zhu W, Chen N, Li P, He K and Gong J: Cathepsin B in hepatic Kupffer cells regulates activation of TLR4-independent inflammatory pathways in mice with lipopolysaccharide-induced sepsis. Nan Fang Yi Ke Da Xue Xue Bao 38: 1465-1471, 2018 (In Chinese).

52. Zhang WJ, Fang ZM and Liu WQ: NLRP3 inflammasome activation from Kupfer cells is involved in liver fibrosis of Schistosoma japonicum-infected mice via NF- $\kappa$ B. Parasit Vectors 12: 29, 2019

53. Ohtani $\mathrm{N}$ and Kawada $\mathrm{N}$ : Role of the gut-liver axis in liver inflammation, fibrosis, and cancer: A special focus on the gut microbiota relationship. Hepatol Commun 3: 456-470, 2019.

(i) $(-)$ This work is licensed under a Creative Commons Attribution-NonCommercial-NoDerivatives 4.0 International (CC BY-NC-ND 4.0) License. 